pioneered by Dr Fine and others but that lesson has been learned, and in my view does not justify perpetuation of geriatrics as a separate specialty, the staffing problems of which were always inevitable and apparent to everyone-or almost everyone.

Ipswich

J W Paulley

SIR,-Having recently returned from abroad, I could read the article by $\mathrm{Mr} \mathrm{V} \mathrm{H}$ Cross (24 September, p 816) with the subsequent correspondence, and I am pleased to see that he has escaped in large part the accusations usually levelled against outpourings by the young-naivety, impracticality, arrogance, and downright radicalism. I thought the article sensitive and unusually perceptive, though without reference to the changing climate in the matter of respect for the old. With the decline of observation of Christian teaching and with the Commandments now rarely read in full in Church-the Fifth ${ }^{1}$ is relevant here - it is inevitable that the old should be regarded purely as clinical material and often unrewarding at that. The problems of course are very real. Notching up 70 myself and still giving dental care at geriatric units when requested, I can see that the techniques applicable for both conservative and denture treatment, and the judgment necessary to assess the value of either in any given case, would largely represent unknown territory for the newly qualified, and a forbidding test of morale. A problem exists also for the consultants in overall charge, who would have their quota of young staff assigned to this work. It is true some young people seem to have a natural ability to sympathise with, and care for, the old, and those of my generation knowing we are heading for the dark ourselves should not have any problems in this respect.

Surbiton,

Robert Cutler

Surrey

' Cutler, R, British Dental fournal, 1974, 136, 341.

\section{Medical manpower}

SIR,-It would indeed be unwise for any individual to make categorical statements regarding the current state of medical manpower production in the UK without a considerable number of caveats. I thought I had provided these in my letter which you kindly published (10 September, p 708).

The pitfalls are well illustrated by Professor Parkhouse's reply, published in your issue of 24 September ( $p$ 834), which enables me to identify his error. In fact, the total numbers of doctors qualifying in 1975 can be broken down as follows :

$\begin{array}{lr}\text { English universities } & 2322 \\ \text { University of Wales } & 109 \\ \text { Scottish universities } & 473 \\ \text { Queen's University, Belfast } & 108 \\ \text { Irish universities } & 346 \\ \text { Non-graduate qualifications } & 653\end{array}$

The figure of $2620 \mathrm{~GB}$ graduates which Professor Parkhouse quotes for 1975 is, in fact, nearest to the number of entrants to medical schools of universities in England and Wales in that year, which totalled 2622. Therefore it would seem that Professor Parkhouse has ignored the 615 students who entered Scottish universities in that year, together with the 139 students who entered

Queen's University, Belfast. At the present time both these provinces lie within the UK.

The number of students admitted to medical schools in 1975 may be broken down as follows:

$$
\begin{array}{lr}
\text { English universities } & 2502 \\
\text { University of Wales } & 120 \\
\text { Scottish universities } & 615 \\
\text { Queen's University, Belfast } & 139 \\
\text { Irish universities } & 402
\end{array}
$$

Of the 653 doctors who qualified by gaining non-university qualifications, an unknown number may have also passed a university examination, but it would be wrong to assume that they all studied in a UK university.

I hope this illustrates the dangers and the difficulties of medical manpower planning, and I cannot overemphasise that these figures apply to a specific year only. The entrants to medical school courses in anatomy and physiology for the year 1970 (which might, to a degree, relate to the number of graduates in 1975) were as follows:

$\begin{array}{lr}\text { English universities } & 2110 \\ \text { University of Wales } & 107 \\ \text { Scottish universities } & 496 \\ \text { Queen's University, Belfast } & 105 \\ \text { Irish universities } & 387\end{array}$

For what they are worth, these figures might suggest that the fall-out for UK medical schools is not high. Professor Parkhouse's numerical error, therefore, lies between 955 and 1610 , which is somewhat in excess of the possible $2 \%$ error to which he admits. However, he is quite right, I may have been guilty of exaggeration when I suggested a possible numerical error of 1000 . The minimal error in Professor Parkhouse's document is made up as follows. In 1975 entrants to Scottish medical schools 615, entrants to Queen's University, Belfast 139, plus half the intake of the Irish universities in that year 201 (half the 1975 Irish entrants will no longer be able to emigrate to the United States as their predecessors have done), totalling 955. For the upper limit of error, I have added the total qualifying in 1975 by non-university qualifications. Of course, the comparable figure should be the addition to 955 of the, as yet unknown, number of doctors who will qualify through these examinations in 1980 .

I very much regret that papers containing misleading data and errors of this magnitude should be published, since they render the already muddy water even murkier. I trust Professor Parkhouse is now able to identify the source of his error, and will agree that the conclusions in his paper of 20 August can no longer be defended. My thanks are due to the late Alexander Graham Bell and the Japanese electronics industry, without whose inventiveness this study would have been even more tedious. Similarly, it is easy for any individual who cares to do so to confirm or refute the data I have presented, using such equipment.

Gosforth,

P R J VICKERS

Newcastle upon Tyne

**We sent a copy of this letter to Professor Parkhouse, whose reply is printed below.ED, $B M \mathcal{F}$.

SIR,-I am grateful to you for arranging for me to see Mr Vickers's letter. I am afraid detailed comment is likely to be tedious for most readers, but it may be useful to sort out some things. Mr Vickers uses only a small selection of the available data, and misconstrues it. His quite unfounded suggestions about the origin of my figures, for example that Scottish students were ignored, are of course incorrect and deserve no further comment.

The first three figures in Mr Vickers's first table cannot be added to give a correct total for England, Scotland, and Wales. The "English universities" figure, as returned to the GMC each year, is consistently higher than the UGC figure for newly qualified doctors, and the discrepancy can be explained by the inclusion of many Oxford and Cambridge graduates in London medical school lists. The UGC total for those obtaining a first registrable qualification, from medical schools in Great Britain, in the year ending 31 July 1975 was 2664. This included non-degree qualifiers. The same figure was quoted by the Review Body, ${ }^{1}$ and the Church House Conference ${ }^{2}$ gave a total of 2672. This discrepancy, trivial in the present context, was noted in the BMA's evidence on manpower to the Royal Commission. ${ }^{3}$ It would indeed be surprising if the medical schools of England, Scotland, and Wales produced almost 200 more graduates in 1975 than the number of students they admitted in 1970 , which is what a comparison of Mr Vickers's first and third tables might suggest to the uncritical reader. To say that the "fall-out for UK medical schools is not high" would be an understatement of some magnitude; in fact, the drop-out rates are watched quite closely by the UGC and for the last few years have been between 5 and $10^{\circ} \%$. The actual figure quoted ${ }^{1}$ for students admitted to preclinical courses at medical schools in Great Britain in 1970 was 2695, and the true 1975 admissions figure given in response to a parliamentary question on 1 November $1976,{ }^{4}$ and which agrees with the UGC figure, was 3459.

Not every doctor who qualifies from a British medical school enters the NHS immediately. In the course of our own studies, recently reported in the $B M \mathcal{}$," we were able to identify 2628 qualifiers from England, Scotland, and Wales during the calendar year 1975 who took up preregistration posts. During the same calendar year the GMC granted provisional registration to 2652 doctors, including some from abroad. I do not believe, therefore, that my model showed any significant departure from the true state of affairs. There was no "error" in omitting Belfast graduates, since the inflow in question was defined as from "Great Britain," and Irish doctors were included in the approximate overseas total as noted in my previous letter. ${ }^{\circ}$

Mr Vickers's figure of 653 for doctors gaining non-graduate qualifications in 1975 is also misleading. The United Kingdom total was 553 . The remaining 100 were presumably the 100 Irish doctors who qualified from the Royal College of Surgeons in Ireland and who should be added to the 346 university graduates to give a true figure fairly close to my approximation for the total output of the medical schools of the Republic of Ireland. The statistics of non-university qualification in the UK are worth looking at in a little more detail. Maynard and Walker" estimated that "perhaps as many as 200 doctors, including a number of overseas doctors" obtain only a non-University qualification each year. The available figures, for 1974, show that, of a total of 517 nondegree qualifiers, 237 did not have any other registrable qualification. These would include overseas doctors seeking a diploma for registration purposes. In 1975 the UK total of 553 contained 137 diplomates who were not from British medical schools. It may therefore be inferred that the number of British students 